\title{
Long-Run and Short-Run Dynamics of the Exchange Rate in Pakistan: Evidence From Unrestricted Purchasing Power Parity Theory
}

\section{Muhammad Arshad Khan* and Abdul Qayyum**}

\begin{abstract}
The main focus of this paper is to measure the speed of adjustment of the exchange rate by means of the persistent profile approach developed by Pesaran and Shin (1996) to examine the symmetry and proportionality assumptions of the purchasing power parity (PPP) theory of exchange rates for the Pak-rupee vis-à-vis the US-dollar exchange rate over the period 1982Q2-2005Q4. Using cointegration and vector error-correction modeling approaches, we find considerable support for the validity of weak-form PPP in Pakistan. Furthermore, the symmetry and proportionality assumptions of PPP are not verified. In the short-run, the exchange rate and foreign prices play a significant role in the convergence process to achieve long-run equilibrium. However, the speed of adjustment is very slow and the persistence profiles suggest that almost 4-5 years are required to eliminate deviations and bring the nominal exchange rate in line with the long-run equilibrium path.
\end{abstract}

JEL Classification: C13, C22, C51, F31, F37

Keywords: Exchange Rate, Purchasing Power Parity, Cointegration, Vector Error Correction, Pakistan

\section{Introduction}

The relationships between exchange rates, domestic prices and foreign prices have been at the center of policy discussions since the breakdown of the Bretton Woods system. It is widely acknowledged that stability in exchange rates ensures macroeconomic stability which impacts economic growth favorably. Misaligned exchange rates can lead to a reduction in

\footnotetext{
* Senior Research Economist, Pakistan Institute of Development Economics, Islamabad.

** Registrar, Pakistan Institute of Development Economics, Islamabad.
} 
economic efficiency, a misallocation of resources and capital flight. ${ }^{1}$ Consequently, the exchange rate has received considerable attention in macroeconomic policy discussions as an important source of macroeconomic disequilibrium. The purchasing power parity (PPP) hypothesis is one of the oldest propositions establishing the link between exchange rates, domestic and foreign price levels. The theory is based on two key assumptions: the law of one price and long-run neutrality of money. These assumptions are necessary but not sufficient because real shocks may require relative price adjustments which violate PPP (Habermeier and Mesquita, 1999).

PPP theory has far-reaching implications at the theoretical, empirical and policy levels. For instance, PPP is used as a fundamental building block of the monetary approach to exchange rate determination. ${ }^{2}$ Thus testing the PPP hypothesis is important because its findings are used in many current international financial research studies as well as important policy decisions (Baharumshah and Ariff, 1997). In policy terms, exchange rate management is at the center of many financial stabilization plans and PPP provides a theoretical basis for external adjustment policy. PPP is used in the implementation of economic reform programs sponsored by the World Bank and International Monetary Fund and is used as a criterion of exchange rate overvaluation and undervaluation. It also plays a role in the choice between money supply or inflation targeting in the design of monetary policy and is used to compare living standards across countries. Its analysis is also relevant for assessing whether the flexible exchange rate system is successful in insulating the domestic economy from foreign shocks (Frenkel, 1981). PPP implies a high degree of integration between goods and foreign exchange markets. Consequently, the nominal exchange rate between two currencies will adjust the inflation differential in order to keep the real exchange rate constant (Bhatti, 1996 and 2000). PPP is used as a reminder that monetary policy has no long-run impact on the real exchange rate. Thus, countries with different inflation rates should expect that movements in exchange rates adjust to offset these differentials in the long-run.

Despite its simplicity and theoretical appeal, there is inconclusive evidence regarding PPP. PPP theory is silent on issues regarding the process

\footnotetext{
${ }^{1}$ Misalignment of the exchange rate can adversely affect economic growth in three ways: (i) undermine external competitiveness by overpricing exports, (ii) misallocation of resources by distorting domestic prices relative to international prices, and (iii) adversely affecting domestic financial markets by creating uncertainty, encouraging speculation and overvaluation.

${ }^{2}$ For example, the monetary model of exchange rate determination assumes continuous PPP, while the sticky price exchange rate models allows short-run exchange rate deviations from PPP.
} 
of convergence towards the long-run equilibrium. Recently, researchers have shifted their interest from testing long-run PPP or stationarity of real exchange rates to measure the speed of adjustment back to an equilibrium (Coakley and Fuertes, 2000). The slow speed of adjustment and a very high volatility of real exchange rates in the short-run are central to the PPP puzzle (Rogoff, 1996). The consensus suggests a speed of reversion of $15 \%$ per annum, equivalent to half-lives of around 3 to 5 years (Boyd and Smith, 1999; Engle and Morley, 2001). The literature suggests that the root cause of the PPP puzzle lie in the different speeds of convergence for nominal exchange rates and prices (Cheung et al., 2004). Engle and Morley (2001) argued that nominal exchange rates do converge at a much slower rate than prices and the half-lives of exchange rates range from 3 to 6 years, whereas half-lives of prices are about 1 to 2 years. However, Cheung et al. (2004) shows that around $60-90 \%$ of PPP disequilibrium adjustment take place through nominal exchange rate adjustment rather than price adjustment. Hence, the observed rate of PPP reversion depends on the speed of nominal exchange rate convergence.

Many of the existing studies on short-run PPP dynamics follow the structural vector autoregressive (VAR) of Clarida and Gali (1994). Under this approach, orthogonalized impulse response functions are employed to measure the impact of shocks to individual variables. However, one major drawback of this approach is that the impulse response functions are not uniquely identified (Coakley and Fuertes, 2000). Pesaran and Shin (1996) proposes the persistent profile approach to measure the speed of adjustment of the real exchange rate. The persistent profile approach measures the rate of mean reversion of the exchange rate on system-wide rather than variable specific shocks. Unlike the standard approach, it does not require any strong exogeneity property of the variables involved in PPP and provides information on the shape of the whole adjustment path (Helg and Serati, 2000).

Extensive research has been carried out to examine the validity of the PPP hypothesis. This work can be divided into seven main groups. ${ }^{3}$ First, a number of studies carried out, inter alia, by Frenkel (1978), Krugman (1978), Ardeni and Lubian (1989) and Taylor (1992) examined the validity of the PPP hypothesis and found supportive evidence for almost all exchange rates except for those involving the US-dollar. Second, studies by Taylor (1988), Giovannetti (1989), Patel (1990), Nachane and Chrissanthaki (1991), Crowder (1992), Sarantis and Stewart (1993), MacDonald (1993), Cooper (1994), Corbae and Ovliaris (1988), Arderi and Lubin (1991), Dornbusch (1988) and Moosa and Bhatti (1996) investigated the validity of PPP theory

\footnotetext{
${ }^{3}$ For further detail, see Bhatti (2000).
} 
for the post-Bretton Woods floating exchange rates system and failed to produce supportive evidence for long-run PPP. ${ }^{4}$ Third, studies conducted by McNown and Wallace (1989), Liu (1992) and Mahadavi and Zhou (1994) found supportive evidence for countries experiencing hyperinflation. Fourth, Lothain (1990), Ardeni and Lubian (1991) and Moosa (1994) produced supportive evidence using low frequency data. Fifth, studies by Huizinga (1987), Kaminskyu (1987), Abauf and Jorion (1990) and Whitt (1992) reported supportive results real exchange rate mean reversion. Sixth, studies conducted by Frankel and Rose (1996), Oh (1996), Wu (1996), Pappel (1997), Cheung and Lai (1998, 2000), Taylor and Sarno (1998), Wu and Wu (2001), Engle (2000), Engle and Morley (2001) and Cheung et al., (2004) generally found supportive evidence of PPP reversion. The overall results of these studies suggested estimates of the reversion speed with half-lives ranging from 3 to 5 years. Sixth, studies by Helg and Serati (2000) and Coakley and Fuertes (2000) found that the effect of system-wide shocks on long-run PPP was persistent with the average half-lives ranging between 6 to 8 years. It is clear from the survey of literature that the empirical results have been mixed and conflicting.

The behavior of the exchange rate and its responses to nominal and real shocks as a part of the macro-adjustment process has great relevance for policy-making in Pakistan, which has recently shifted to a market-based exchange rate regime. Pakistan opted for a managed floating exchange rate system in January 1982. In July 2000, the exchange rate policy shifted from a managed float to free flexible exchange rate.' Changes in the exchange rate regime are expected to eliminate deviations from parity. Besides changes in the exchange rate regime, trade and financial liberalization and loosening of restrictions on capital inflows during the past decade and a half have reduced many distortions. These structural changes may force the parity condition to converge towards the long-run equilibrium path. It is therefore interesting to determine whether the liberalization of the domestic economy prompts major shifts in the price structure by increasing convergence towards the law of one price.

The empirical evidence associated with Pakistan on this issue is still sparse (Chishti and Hasan, 1993; Bhatti, 1996, 2000; Liew et al., 2004; Tang and Butiong, 1994; Yunus, 2000, Ahmed and Khan, 2002 and Qayyum et al.,

\footnotetext{
${ }^{4}$ It must be noted that the majority of the studies conducted have been on developed countries and a limited number on high inflation developing countries.

${ }^{5}$ Adjustment to parity is made through the movements in domestic price level in a fixed exchange rate regime, while in the case of a managed floating exchange rate, parity reversion takes place through the movements in exchange rates (Froot and Rogoff, 1995).
} 
2004). These studies found supportive evidence, while Chishti and Hasan (1993) found evidence which does not support the PPP hypothesis. Except Yunus (2000), Ahmed and Khan (2002), Qayyum et al. (2004) and Khan and Qayyum (2007), these studies do not take into account the short-run dynamics of the exchange rate and domestic and foreign prices. However, all the studies imposed symmetry and proportionality assumptions a priori and tested a restricted version of PPP. Furthermore, no serious attempt has been made to measure the speed of mean reversion of PPP in the system-wide context in Pakistan. This study attempts to fill this gap.

Given the paramount importance of exchange rate dynamics in macroeconomic adjustment, this paper attempt to measure the speed of adjustment to PPP by means of the "persistent profile" based on the unrestricted PPP using quarterly data over the period 1982Q2-2005Q4. This study significantly differs from earlier studies conducted on this issue in Pakistan. First, unlike previous studies we have estimated unrestricted PPP using cointegration and vector error-correction modeling approaches that encapsulate short-run dynamics and the long-run response of the exchange rate to changes in domestic and foreign prices. Second, this study has focused on testing the validity of the symmetry and proportionality assumptions of PPP. Third, we have used persistent profiles of PPP to measure the speed of convergence towards the long-run equilibrium path.

The rest of the paper is organized as follows: section 2 deals with the theoretical modeling of purchasing power parity, methodology and data. Cointegration analysis is carried out in section 3. Persistence profiles of PPP are given in section 4 , while some concluding remarks are given in the final section.

\section{Modeling Purchasing Power Parity Theory, Methodology and Data}

PPP is one of the oldest and widely tested propositions in international finance. Its intellectual origins can be traced back to the Salamanca School in the $16^{\text {th }}$ century in Spain. Its revival as a theory of exchange rate determination began with the writings of Cassel (1918). ${ }^{6}$ The absolute version of PPP states that the nominal exchange rate is determined by the ratio of domestic and foreign price levels. This version of PPP assumes symmetry and proportionality restrictions a priori. These assumptions may be overly restrictive because the effect of domestic and foreign prices need not be proportional and symmetric. Following Ardeni and Lubian (1989), we include domestic prices and foreign prices

\footnotetext{
${ }^{6}$ An excellent of historical review of PPP can be found in Dorrnbusch (1988).
} 
unrestrictedly. Define $s$ as the nominal exchange rate measured in terms of Pak-rupees per unit of US-dollar and $p$ as the domestic price level. Let an asterisk denote a foreign variable and lowercase letters indicate that the variables have been transformed using the natural logarithms. The testable version of the unrestricted PPP relationship is given by:

$$
s_{t}=\alpha_{0}+\alpha_{1} p_{t}+\alpha_{2} p_{t}^{*}+\omega_{t}
$$

Where $\alpha_{0}$ is constant, $\alpha_{1}$ and $\alpha_{2}$ are the coefficients of domestic and foreign prices respectively and $\omega_{t}$ is a stochastic disturbance term representing deviations of the real exchange rate around the mean. The PPP hypothesis is based on the assumption of the law of one price, which implies that in a competitive and integrated market, the price of a given good would be the same when quoted in different currencies. In the shortrun, the exchange rate could diverge from PPP because of various impediments on trade and capital inflows, speculative activities of economic agents, intervention in the foreign exchange markets and productivity differentials in the exports sector.

A large number of researchers have used the cointegration approach to test the validity of the PPP hypothesis and found that the error term is stationary (i.e. $\left.\omega_{t} \sim I(0)\right)$ and that symmetry $\left(\alpha_{1}=-\alpha_{2}\right)$ and proportionality $\left(\alpha_{1}=\alpha_{2}=-1\right)$ conditions are satisfied (MacDonald and Marsh, 1997). An alternative strand of the empirical literature involves imposing symmetry and proportionality assumptions a priori on the exchange rate and relative prices to examine whether the real exchange rate is following a mean-reverting process. That is:

$$
q_{t}=\delta+\lambda q_{t-1}+\zeta_{t}, \quad 0<\lambda<1
$$

where $\delta$ and $\zeta$ are respectively the intercept and error terms. The real exchange rate $q_{t}$ is equal to $s_{t}+p_{t}^{*}-p_{t}$. PPP holds only when the real exchange rate is stationary. But this is the most restrictive form of PPP. Relative PPP requires that $\delta=0$, while absolute PPP requires that both $\delta=0$ and $\lambda=0$ (Doganlar, 1999). 
The strong version of the less restrictive PPP implies that $\alpha_{1}=-\alpha_{2}=1, \alpha_{0}=0^{7}$ and $\omega_{t}$ is stationary. However, the homogeneity restriction $\alpha_{0}=0$ is often relaxed due to the presence of transaction costs and other impediments to trade. The symmetry $\left(\alpha_{1}=-\alpha_{2}\right)$ and proportionality $\left(\alpha_{1}=-\alpha_{2}=1\right)$ restrictions can be relaxed due to measurement errors (Taylor, 1988; Cheung and Lai, 1993; Sercu et al., 1995). In testing the validity of unrestricted PPP we use cointegration and vector error-correction modeling techniques.

In Pakistan, the period after 1990 is associated with significant changes in trade and financial policy. Prior to the reforms of the 1990s, the foreign exchange market was heavily regulated by the State Bank of Pakistan (SBP) through exchange controls. All foreign exchange transactions were conducted through authorized dealers (ADs) and authorized money changers (AMCs) at the SBP's subscribed rate. On the other hand, inter-bank transactions were taking place at rates varying within the range set by SBP's buying and selling spread. ${ }^{8}$ The exporters, remitters and tourists were the main suppliers of the foreign exchange, whereas importers and the government organizations were the major users of the foreign exchange. To manage the transactions between suppliers and users of foreign exchange, a system of ADs and AMCs was in place (SBP, 2000). After the 1990s, the government introduced reforms to promote the foreign exchange market and improve the payment system. These reforms included: elimination of black market, rupee opening of resident foreign currency accounts, rupee convertibility on the current account, unification of the exchange rate, and adoption of a free and flexible exchange rate system. ${ }^{9}$ Furthermore, several other steps were taken to create a regulatory and institutional framework to enhance the role of market forces in the process of exchange rate determination (Janjua, 2004). ${ }^{10}$ These institutional and structural changes complicate the process of exchange rate determination. To capture the

7 The proportionality restriction may be imposed on equation 1 by restricting $\alpha_{0}=0, \alpha_{1}=1, \alpha_{2}=-1$. The symmetry hypothesis implies that $\alpha_{0}=0$, $\alpha_{1}=-\alpha_{2}$.

${ }^{8}$ The spread between the buying and selling rate was equal to Rs. 0.0156 per US-dollar up to April 24, 1978, and afterwards it was changed to 0.5 percent of the spot buying rate (SBP, 2002).

${ }^{9}$ For further detail see SBP’s Financial Sector Assessment Reports 1990-2000, 2001-02, and 2005-06.

${ }^{10}$ These steps included development of staffed and well-equipped dealing room of foreign exchange at SBP, upgradation of information systems, creation of dealing rooms by banks, providing guidelines for the proclamation of code of conduct, development of a forward market and liberalization of the limits of foreign exchange holdings by banks (Janjua, 2004, p. 454). 
effect of these changes, we introduced two policy dummies and one event dummy in the VAR mode1.

Thus our VAR model includes restricted intercepts and three unrestricted seasonal dummies. In addition, a dummy variable $\left(D_{91}\right)$ for the period 1991-2005 was added to the model to capture the effects of financial sector reforms that took place in the early 1990s. Similarly, in order to identify a possible structural break associated with the May 1998 nuclear tests and the change in the exchange rate regime from managed float to free flexible in July 2000, we introduced two additional dummies $D_{98}$ and $D_{00}$ into the VAR mode1. ${ }^{11}$ The vector error-correction model (VECM) is in general given by:

$\Delta X_{t}=\mu-\Pi X_{t-1}+\Gamma_{1} \Delta X_{t-1}+\ldots \ldots \ldots . .+\Gamma_{k-1} \Delta X_{t-k+1}+\varepsilon_{t}$

Where $X=\left[\begin{array}{lll}s_{t} & p_{t} & p_{t}^{*}\end{array}\right]^{\prime}, \Delta=1-L, \Pi$ can be written as $\Pi=\alpha \beta^{\prime}$, where $\beta$ is the coefficient matrix, $\alpha$ is a matrix of adjustment coefficients

\footnotetext{
${ }^{11}$ It can be argued that these transformations could affect not only the real exchange rate but also effect the domestic price level. In May 28, 1998, Pakistan conducted nuclear tests. In response, the world community imposed economic sanctions, which created a situation of economic crisis. Nuclear detonation created the state of uncertainty regarding the ability of Pakistan to meet its external obligations. It is a fact that Pakistan's economy was much more vulnerable to the loss of support from International Monetary Fund (IMF) and other International Financial Institutions (IFIs) when a US-led coalition withheld IMF support. The resulting collapse of confidence created a balance of payment crisis and a significant decline in economic activities. Capital inflows, especially worker remittances, fell drastically and new foreign loans virtually stopped. Foreign exchange reserves fell to extremely low levels. To meet this uncertain situation the authorities froze foreign currency accounts, adopted a two-tier exchange rate system, prevented speculative activity in the inter-bank Forex market, discouraged capital outflows, contained import demand and discouraged overdue export bills among other steps. In November 1998, the US government waived a number of sanctions; at that time, Pakistan's foreign exchange reserves stood at only $\$ 458$ million. The open (kerb) market rate of the Pak-rupee/US dollar depreciated from Rs. 45 in the early May 1998 to Rs. 63 in mid-July 1998, showing $28 \%$ depreciation. At the end of 1998, when most of the sanctions had been lifted, the Pak-rupee remained $16 \%$ below its pre-test value. The economic sanctions imposed by the world community caused a collapse in the confidence of investors. As a result, the Karachi Stock Exchange (KSE) index after May 1998 sharply fell by 34\%, more than the rest of the Asian Stock markets. The KSE index reached an all time low level 777.26 three days after the announcement of economic sanctions. However, receiving financial support from the Arab world enabled Pakistan to steer the economy successfully from the crisis.
} 
and $\varepsilon_{t}=\left[\begin{array}{lll}\varepsilon_{1 t} & \varepsilon_{2 t} & \varepsilon_{3 t}\end{array}\right]^{\prime}$ is a vector of white-noise innovations. The VECM with the PPP restrictions has the following structure (Chinn (1999, 2000):

$$
\begin{aligned}
& \Delta s_{t}=\mu_{1}-\phi_{1} z_{t-1}+\sum_{i=1}^{k} \gamma_{1 i} \Delta s_{t-i}+\sum_{i=1}^{k} \psi_{1 i} \Delta p_{t-i}+\sum_{i=1}^{k} \lambda_{1 i} \Delta p^{*}{ }_{t-i}+D^{\prime}+\varepsilon_{1 t} \\
& \Delta p_{t}=\mu_{2}-\phi_{2} z_{t-1}+\sum_{i=1}^{k} \gamma_{2 i} \Delta s_{t-i}+\sum_{i=1}^{k} \psi_{2 i} \Delta p_{t-i}+\sum_{i=1}^{k} \lambda_{2 i} \Delta p^{*}{ }_{t-i}+D^{\prime}+\varepsilon_{2 t} \\
& \Delta p_{t}^{*}=\mu_{3}-\phi_{3} z_{t-1}+\sum_{i=1}^{k} \lambda_{3 i} \Delta s_{t-i}+\sum_{i=1}^{k} \psi_{3 i} \Delta p_{t-i}+\sum_{i=1}^{k} \lambda_{3 i} \Delta p^{*}{ }_{t-i}+D^{\prime}+\varepsilon_{3 t}
\end{aligned}
$$

Where $z_{t-1}=\beta^{\prime} X_{t-1}$ represents the error correction term with coefficients, $1>\phi_{1}>0,1>\phi_{2}>0$ and $1>\phi_{3}>0 . D$ is the vector of dummies (i.e. three seasonal dummies, two policy dummies and one event dummy). In the above equation system, $\phi<0$ implies that there is a tendency for the exchange rate to return to the path of long-run equilibrium. When $\phi=0$, no adjustment takes place to bring the exchange rate towards its long-run equilibrium path and if $\phi>0$, the exchange rate follows overshooting behavior. We applied the Johansen (1988) and Johansen and Juselius (1990) maximum likelihood method to estimate the VECM and to test for cointegration. Following the Cheung and Lai (1993) testing procedure, we applied the likelihood ratio test to implement the coefficient restrictions, that is $\left(\alpha_{1} \alpha_{2} \alpha_{3} \alpha_{0}\right)=\left(\begin{array}{llll}1 & -1 & 1 & 0\end{array}\right)$ and then tested the symmetry restriction $\left(\alpha_{2}=-\alpha_{3}\right)$ and proportionality restriction $\left(\alpha_{2}=-\alpha_{3}=1\right)$.

The data set used in this study consists of quarterly observations covering the period from $1982 \mathrm{Q} 2$ to $2005 \mathrm{Q} 4 .^{12}$ Our model contains three variables, the exchange rate $\left(s_{t}\right)$ defined as the average market rate measured in terms of units of Pak-rupee per US-dollar. $p_{t}$ is the domestic price level proxied by the wholesale price index (WPI) and $p_{t}^{*}$ is the foreign

\footnotetext{
${ }^{12}$ Although the sample size in terms of time horizon is relatively small, which affects the performance of PPP because 2-10 years are needed for PPP to be re-established (Hendry, 1986). Due to this we increase sample size by time disaggregating to establish a long-run relationship between the exchange rate, domestic and foreign prices. The effects of increasing the sample size by the use of higher frequency data over a fixed sample period in unit root tests are also analyzed by Shiller and Perron (1985).
} 
price level proxied by the US producer price index (PPI). ${ }^{13}$ All the data were retrieved from the International Financial Statistics (IFS) CD-ROM (2006).

\section{Cointegration Analysis: Test of PPP Hypothesis}

We first examine time series properties of the data by using the Augmented Dickey Fuller (ADF) unit root test. To capture the effects of seasonality we use seasonal dummies in the ADF test, but this makes no difference in the results. The results of ADF test are reported in Table-1. The results suggest that the real exchange rate $\left(q_{t}\right)$ is non-stationary at loglevel and stationary at log-first difference implying no mean reversion. Parikh and Williams (1990) and Wu (1996) argued that the studies based on short spans of data find it difficult to prove that there is any mean reversion in the real exchange rate.

Table-1: Results of ADF Unit Root Tests

\begin{tabular}{lccccc}
\hline Series & \multicolumn{2}{c}{ Log-Level } & \multicolumn{2}{c}{ Log-First Difference } & \multirow{2}{*}{ Decision } \\
\cline { 2 - 5 } & C & C + D & C & C + D & \\
\hline$S$ & $-1.288(1)$ & $-1.264(1)$ & $-6.618(0)^{*}$ & $-6.461(0)^{*}$ & I (1) \\
$P$ & $-0.544(1)$ & $-0.504(4)$ & $-7.284(0)^{*}$ & $-3.941(2)^{*}$ & I (1) \\
$p^{*}$ & $-2.524(3)^{\mathrm{T}}$ & $-2.524(3)^{\mathrm{T}}$ & $-6.321(0)^{* \mathrm{~T}}$ & $-6.321(0)^{* \mathrm{~T}}$ & I (1) \\
$q$ & $-1.612(2)$ & $-1.517(2)$ & $-6.769(1)^{*}$ & $-6.828(1)^{*}$ & I (1) \\
\hline
\end{tabular}

Note: C, T, D stands for constant, trend and seasonal dummies. Figures in brackets indicates lag length, while * indicates significance at the $1 \%$ level of significance.

All other series are non-stationary at their log-level and stationary at their first difference. Thus we conclude that $s, p, p^{*} \sim$ I (1). Since all variables to be entered in the PPP model are integrated of order I (1), it is possible to test for the existence of cointegration between the exchange rate, domestic and foreign prices.

The Johansen multivariate cointegration approach is used to examine the long-run relationship between the nominal exchange rate, domestic and

\footnotetext{
${ }^{13}$ We used (WPI) wholesale price indices $(2000=100)$ for both Pakistan and the U.S. because the domestic prices based on the consumer price indices (CPI) seems to be I(2) i.e. $p^{c p i} \sim$ I (2) while the exchange rate $s \sim$ I (1).
} 
foreign price levels. The VAR model is specified with two lags. ${ }^{14}$ Moreover, single equation and multivariate residual-based misspecification tests with respect to serial correlation up to order $5, \mathrm{ARCH}$ and heteroscedasticity up to order 4 are found to be insignificant except for the assumption of normality (Table-2) $)^{15}$. This could be due to the large residuals in the foreign price and exchange rate equations (See Figure-1).

Table-2: Multivariate Residual-based Misspecification Tests

\begin{tabular}{lcccccc}
\hline Equation & \multicolumn{7}{c}{ Equation Diagnostics } \\
\cline { 2 - 7 } & $\begin{array}{c}\text { Portmanteau } \\
\text { (10) }\end{array}$ & $F_{A R}(1-5)$ & $\chi^{2}{ }_{N d}(2)$ & $F_{A R C H}(1-4)$ & $F_{H e t}$ & $F_{H e t}-x$ \\
& 4.92 & 0.95 & 27.04 & 1.51 & 0.83 & 0.72 \\
\hline $\boldsymbol{s}_{\boldsymbol{t}}$ & & $(0.45)$ & $(0.00)^{*}$ & $(0.21)$ & $(0.62)$ & $(0.82)$ \\
& & 1.05 & 3.92 & 1.36 & 0.70 & 0.70 \\
$\boldsymbol{p}_{\boldsymbol{t}}$ & 9.21 & $(0.40)$ & $(0.14)$ & $(0.26)$ & $(0.75)$ & $(0.84)$ \\
& & 1.23 & 6.85 & 1.10 & 1.28 & 1.69 \\
$\boldsymbol{p}_{\boldsymbol{t}}{ }^{*}$ & 10.48 & $(0.30)$ & $(0.03)^{* *}$ & $(0.36)$ & $(0.25)$ & $(0.05)$ \\
& & & & & & \\
\hline
\end{tabular}

\begin{tabular}{lccccc}
\hline \multicolumn{7}{c}{ System Diagnostics } \\
\hline System & Portmanteau: & $F_{A R}(1-5)$ & $\chi^{2}{ }_{N d}(6)$ & $F_{H e t}$ & $F_{H e t}-x$ \\
Diagnostics & 10 lags & $(45,190)$ & & $(72,348)$ & $(162,290)$ \\
\hline VAR & 87.59 & 1.19 & 35.65 & 1.01 & 1.08 \\
& & $(0.21)$ & $(0.00)^{*}$ & $(0.46)$ & $(0.28)$ \\
\hline
\end{tabular}

Note: In the single equations, the following null hypotheses are tested for each of the three equations in the VAR model: absence of autocorrelation up to order 5, normally distributed errors, no ARCH and heteroscedasticity effect up to order 4. At the system level, the hypotheses of no autocorrelation, non-normality and no heteroscedasticity are tested. Figures in brackets indicate the p-values.

\footnotetext{
${ }^{14}$ Number of lags selected for VAR is based on the minimum values of Akaike Information Criterion (AIC).

${ }^{15}$ Cheung and Lai (1993) and Gonzalo (1994) have demonstrated the robustness of the Johansen procedure to non-normality. Also see note below Table-2.
} 
Figure-1: Parameter Constancy Test
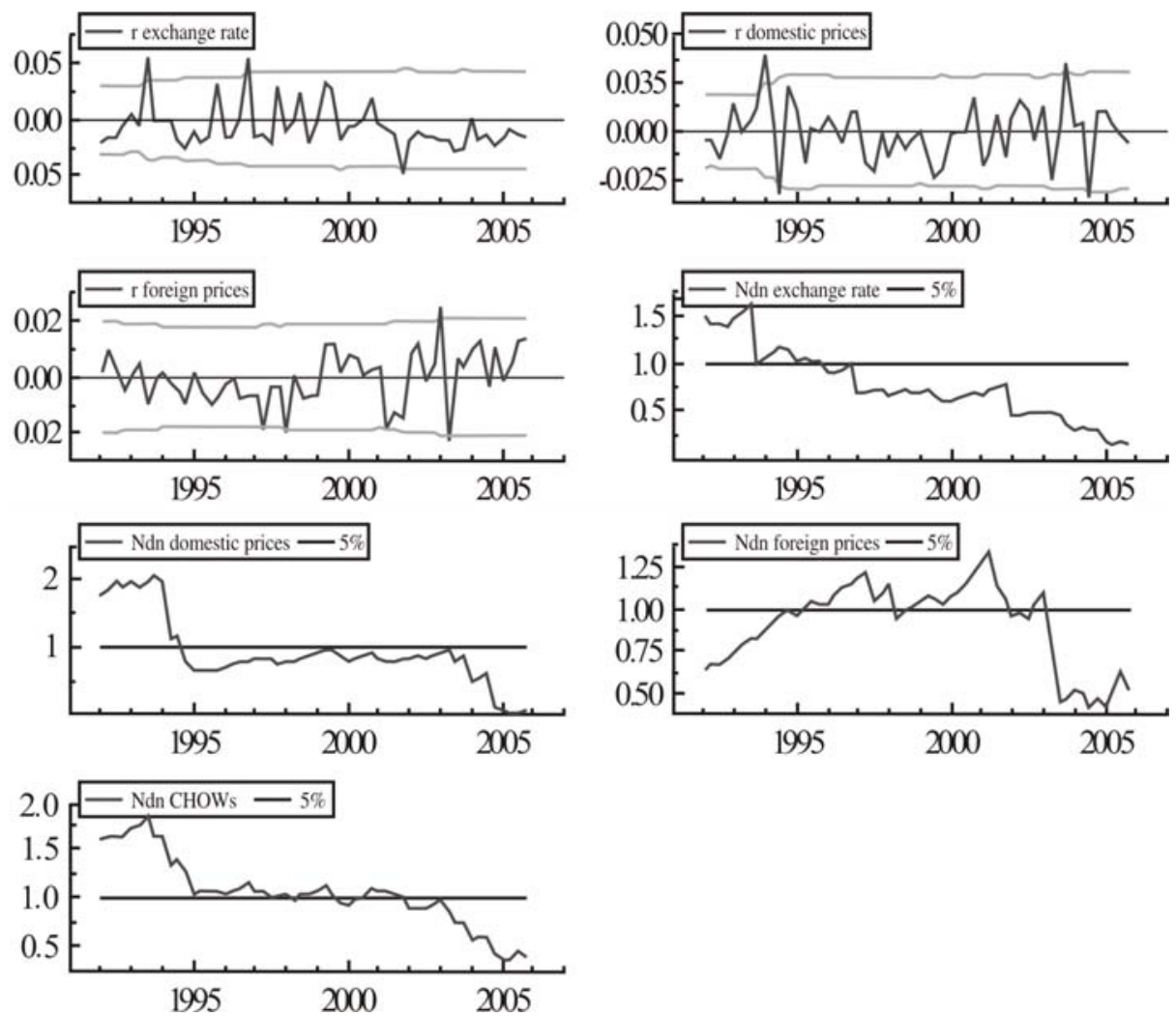

The model constancy test statistics are obtained by recursive estimation of the VAR model. For each of the equations, one-step ahead residuals +/-2SE in the first three parts of Figure-1 and Chow breakpoints are shown in the second three parts, while Ndn Chows are shown in the last part of the Figure. These Chow statistics are scaled by their critical values at the 5 percent level. As can be seen from the Figure, the Chow test does not reject the hypothesis of parameter stability for exchange rate equation. It implies that estimated parameters of the VAR model are constant.

The results presented in Table-3 (panel A) reveals that there is cointegration between exchange rate, domestic and foreign price levels because the hypothesis of no cointegration is rejected at the $5 \%$ level of significance using either maximum eigenvalue $(\lambda-\max )$ or trace $(\lambda-$ trace $)$ statistics. Both $\lambda$-max and $\lambda$-trace suggest the existence of one cointegrating vector. The existence of cointegration implies that there exists long-run comovement between the exchange rate, domestic and foreign prices, and weak-form PPP holds for Pakistan. 
Table-3: Cointegration Analysis of the PPP Hypothesis Series $\left[s_{t}, p_{t}, p_{t}^{*}\right]$ and lags $=2$

\begin{tabular}{lcccc}
\hline \multicolumn{5}{c}{ Panel A: Cointegration Analysis } \\
\hline Eigenvalue & - & 0.2235 & 0.1157 & 0.0207 \\
Hypothesis & $r=0$ & $r<=1$ & $r<=2$ & $r<=3$ \\
$\lambda-$ max & 23.777 & 13.525 & 1.966 & \\
& $(0.031)^{* *}$ & $(0.213)$ & $(0.784)$ & \\
$\lambda-$ trace & 37.302 & 13.525 & 1.966 & \\
Log & $(0.027)^{* *}$ & $(0.331)$ & $(0.780)$ & \\
Likelihood & 788.6489 & 800.5376 & 806.3169 & 807.3000 \\
\hline \multicolumn{5}{c}{ Panel B: Standardized Eigen Vector (Beta Matrix) } \\
$s_{t}$ & Vector 1 & Vector 2 & Vector 3 \\
$p_{t}$ & 1.0000 & -0.4374 & 0.3298 \\
$p_{t}^{*}$ & -0.9939 & 1.0000 & -0.3548 \\
Constant & 0.47272 & -1.6530 & 1.0000 \\
\hline
\end{tabular}

\begin{tabular}{lccc}
\hline \multicolumn{4}{c}{ Panel C: Standardized Adjustment Coefficients (Alpha Matrix) } \\
\hline$s_{t}$ & -0.1226 & -0.0292 & -0.0369 \\
$p_{t_{*}}$ & -0.0150 & -0.0371 & 0.0454 \\
$p_{t}^{*}$ & -0.0392 & 0.0190 & 0.0291 \\
\hline
\end{tabular}

** Indicates $95 \%$ level of significance. Figures in parenthesis represent pvalues. The critical values are taken from Pesaran et al. (2000). Unrestricted variables: D91, D98, D00 and three seasonal dummies.

The long run equation is obtained by normalizing the estimates of the first cointegrating vector on the exchange rate (panel B of Table-3). The cointegrating coefficients of domestic and foreign prices are correctly signed as predicted by the PPP theory. The coefficient on the domestic price level is equal to 0.99 , which follows the theoretical prediction. However, the coefficient on the foreign price level is equal to -0.47 , which differs substantially from the value predicted by the PPP theory. This implies that the exchange rate responds more quickly to domestic price level than to world price level in the long-run. These results are consistent with the findings by Yunus (2000) in the case of Pakistan. 
Table-4: Results for Coefficient Restrictions Test

$$
\left(s_{t}=\alpha_{1} p_{t}+\alpha_{2} p_{t}^{*}+\alpha_{0}+\omega_{t}\right)
$$

\begin{tabular}{|c|c|}
\hline \multicolumn{2}{|c|}{ Panel A: Coefficients and Coefficient Restrictions } \\
\hline$\alpha_{1}$ & $0.9939(0.1105)^{* *}$ \\
\hline$\alpha_{2}$ & $-0.4727 \quad(0.5485)$ \\
\hline$\alpha_{0}$ & $-1.6625(2.1028)$ \\
\hline$\chi^{2}\left(\alpha_{0}=0\right)$ & $0.4820[0.4875]$ \\
\hline$\chi^{2}\left(\alpha_{1}=1\right)$ & $0.0020[0.9648]$ \\
\hline$\chi^{2}\left(\alpha_{2}=-1\right)$ & $0.8756[0.3486]$ \\
\hline$\chi^{2}\left(\alpha_{1}=-\alpha_{2}\right)$ & $1.2507[0.2634]$ \\
\hline$\chi^{2}\left(\alpha_{0}=0, \alpha_{1}=1, \alpha_{2}=-1\right)$ & $13.445[0.004]$ \\
\hline$\chi^{2}\left(\alpha_{0}=0, \alpha_{1}=-\alpha_{2}\right)$ & $11.419[0.003]$ \\
\hline
\end{tabular}

Panel B: Adjustment Coefficient ( $\alpha$ Matrix)

$\Delta s_{t}$

$-0.1226(0.0303)^{* * *}$

$\Delta p_{t}$

$-0.0150 \quad(0.0220)$

$\Delta p_{t}^{*} \quad-0.0392(0.0151)^{* * *}$

* and ${ }^{* *}$ indicates significance at the $99 \%$ and $95 \%$ level. Figures in (.) indicate standard errors while figures in [.] indicate p-values.

For the validity of strong-form PPP, we test the symmetry and proportionality propositions. The results are reported in Table-4. The coefficient on the domestic price level is statistically significant and close to unity, while the coefficient of foreign price level, although possesses the expected sign, is statistically insignificant and below the value predicted by the theory. The symmetry and proportionality restrictions are rejected, which implies that the exchange rate does not move one-for-one with the prices of two countries. These results are inconsistent with the predictions of PPP theory. Yunus (2000) also found similar results in the case of Pakistan. Wang (2000) also found similar results for seven Asian countries. This implies that the real exchange rate is non-stationary and the long-run PPP conditions are violated.

However, the rejection of the symmetry and proportionality restrictions may be possible due to the presence of transaction and transportation costs and measurement errors in the price variables (Taylor, 
1988; Cheung and Lai, 1993; Sercu et al., 1995). This could be possibly because of differences in consumption preferences across countries, different economic structure and factor endowments, presence of nontraded goods in consumer price indexes and transport costs and trade barriers between Pakistan and United States affecting the cost of production and prices (Doganlar, 1999; Engle, 1992).

Pane1 B of Table-4 provides adjustment coefficients indicating how fast the exchange rate and price levels are adjusted towards the long-run equilibrium path. The results indicate that the adjustment coefficients possess the expected negative signs and are statistically significant apart from the coefficient on domestic price inflation. The adjustment coefficient associated with the exchange rate is relatively large as compared to the foreign price level. The results suggest that around $12 \%$ and $0.04 \%$ of the deviations in PPP are eliminated by changes in the exchange rate and foreign inflation per quarter. This suggests that the response of foreign prices is much weaker than that of the exchange rate, while domestic prices play no role in the adjustment process in the short-run. Furthermore, the exchange rate takes 23 years to adjust back towards long-run equilibrium. These results are consistent with the findings of Yunus (2000) in the case of Pakistan.

Recursive estimation of the long-run parameters (Figure-2) indicates that the estimated parameters lie well within the standard error bands. The estimated parameters show some movement from 1998 to 2001 but do not violate the property of parameter constancy. This could be due to perhaps nuclear tests conducted in May 1998 and the events of 9/11. 
Figure-2: Recursive Estimation of the Long-Run Coefficients
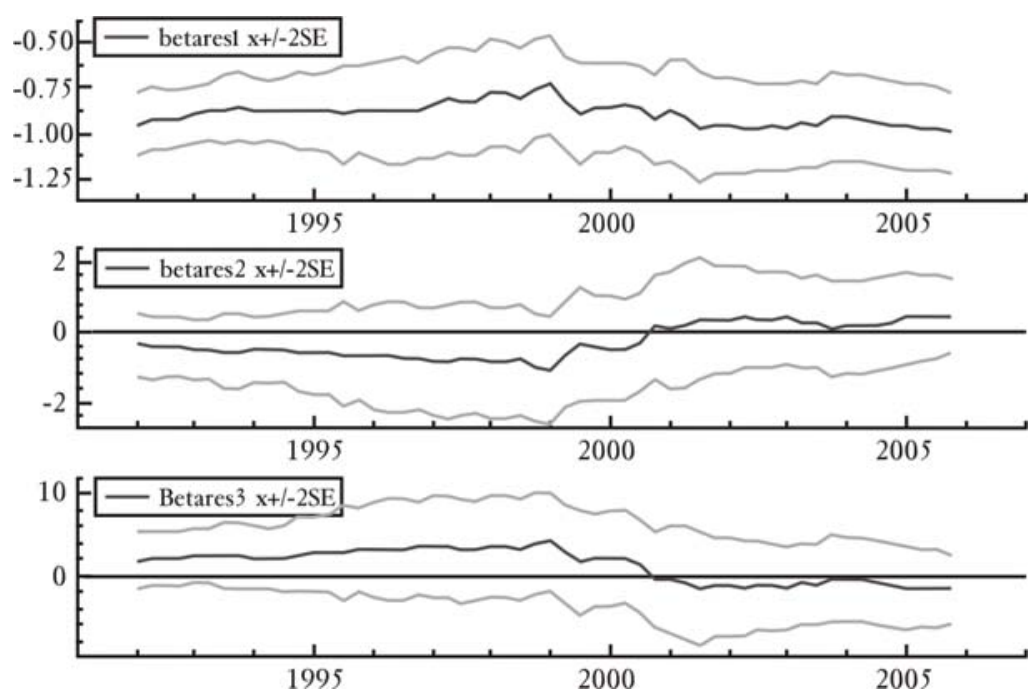

To verify the adjustment process in the short-run, we estimated the VECM to understand the short-run responses of the exchange rate, domestic and foreign inflation. The results are given in Table-5.

The results suggest that the error-correction coefficient on the nominal exchange rate is correctly signed and highly significant, demonstrating the significant role played by arbitrage and the considerable flexibility of prices in restoring long-term equilibrium. The error-correction coefficient on the foreign price level is also correctly signed and statistically significant, implying that the foreign price level is also a significant variable in restoring long-run equilibrium. However, the insignificance of the errorcorrection term associated with the domestic price level implies that domestic prices seem to be weakly exogenous. 
Table-5: Parameters of the Vector Error-Correction Model

\begin{tabular}{|c|c|c|c|}
\hline Variables & $\Delta s_{t}$ & $\Delta p_{t}$ & $\Delta p_{t}^{*}$ \\
\hline$\Delta s_{t-1}$ & $\begin{array}{c}0.3287 \\
(3.7652)^{* *}\end{array}$ & $\begin{array}{c}0.0072 \\
(0.1138)\end{array}$ & $\begin{array}{c}-0.7000 \\
(-1.6230)\end{array}$ \\
\hline$\Delta p_{t-1}$ & $\begin{array}{l}-0.3801 \\
(-2.5210)^{* *}\end{array}$ & $\begin{array}{l}0.2860 \\
(2.6315)^{* *}\end{array}$ & $\begin{array}{c}-0.0208 \\
(-0.2800)\end{array}$ \\
\hline$\Delta p_{t-1}^{*}$ & $\begin{array}{c}0.0485 \\
(0.2263)\end{array}$ & $\begin{array}{c}0.1428 \\
(0.9233)\end{array}$ & $\begin{array}{c}0.3593 \\
(3.3915)^{* *}\end{array}$ \\
\hline$E C M_{t-1}$ & $\begin{array}{c}-0.1226 \\
(-4.0357)^{*}\end{array}$ & $\begin{array}{c}0.0150 \\
(-0.6850)\end{array}$ & $\begin{array}{l}-0.0392 \\
(-2.6149)^{* *}\end{array}$ \\
\hline$S D 1$ & $\begin{array}{c}-0.0103 \\
(-1.7754)\end{array}$ & $\begin{array}{l}0.0087 \\
(2.0758)^{* *}\end{array}$ & $\begin{array}{c}0.0004 \\
(0.1342)\end{array}$ \\
\hline$S D 2$ & $\begin{array}{l}8.67 \mathrm{E}-05 \\
(0.0150)\end{array}$ & $\begin{array}{c}0.0100 \\
(2.3993)\end{array}$ & $\begin{array}{c}-0.0017 \\
(-0.6610)\end{array}$ \\
\hline SD3 & $\begin{array}{c}0.0018 \\
(0.3061)\end{array}$ & $\begin{array}{c}0.0168 \\
(4.0532)^{*}\end{array}$ & $\begin{array}{c}-0.0019 \\
(-0.6610)\end{array}$ \\
\hline D91 & $\begin{array}{c}0.0023 \\
(0.4271)\end{array}$ & $\begin{array}{c}0.0036 \\
(0.9301)\end{array}$ & $\begin{array}{l}-0.0039 \\
(-1.4691)\end{array}$ \\
\hline D98 & $\begin{array}{c}-0.0234 \\
(-1.0374)\end{array}$ & $\begin{array}{c}0.0038 \\
(0.2323)\end{array}$ & $\begin{array}{c}0.0035 \\
(0.3179)\end{array}$ \\
\hline$D 00$ & $\begin{array}{l}-0.0020 \\
(-0.2975)\end{array}$ & $\begin{array}{c}-0.0041 \\
(-0.8546)\end{array}$ & $\begin{array}{c}0.0081 \\
(2.4683)^{* *}\end{array}$ \\
\hline$R^{2}$ & 0.29 & 0.18 & 0.28 \\
\hline $\bar{R}^{2}$ & 0.21 & 0.09 & 0.20 \\
\hline$F-$ statistic & 3.79 & 2.05 & 3.62 \\
\hline S.E equation (sigma) & 0.02 & 0.02 & 0.01 \\
\hline
\end{tabular}


In the exchange rate equation, policy dummies (i.e. D91 and D00) and event dummy (D98) are insignificant implying the stability of the system over the period of study. These results confirm our results reported in Table-3 and Table-4. However, the ability of the estimated simultaneous equation model is limited as indicated by the low adjusted $R^{2}$. Despite this, the estimated VECM provides important information regarding the exchange rate movements in the short-run. The significance of the error-correction coefficients indicates the presence of weak form-PPP and the tendency for the nominal exchange rate to revert to the previous period's equilibrium path. However, the speed of reversion is very slow and takes 2-3 years to converge.

\section{Persistence Profiles of PPP}

The persistence profiles of the PPP relationship are estimated using a VECM to determine the speed at which the variables in the system revert to their long-run values. The idea of persistence profiles to measure the speed of adjustment was proposed by Lee and Pesaran (1993) and Pesaran and Shin (1996). The main advantage of this method is that it does not require the assumption of exogeneity of the variables. Moreover, this measure also describes the full dynamics of the adjustment over the selected horizon. The persistence profiles provide useful information on the speed with which the different relations in the model, once shocked, will return to their longrun equilibrium. Persistence profiles are different from the impulse response functions because they are unique and do not depend on the specifically defined shocks orthogonalization procedure. The persistence profiles estimates for the unrestricted PPP based on the cointegration relationship are reported in Figure-3. 
Figure-3: Estimates of Persistence Profiles of the PPP

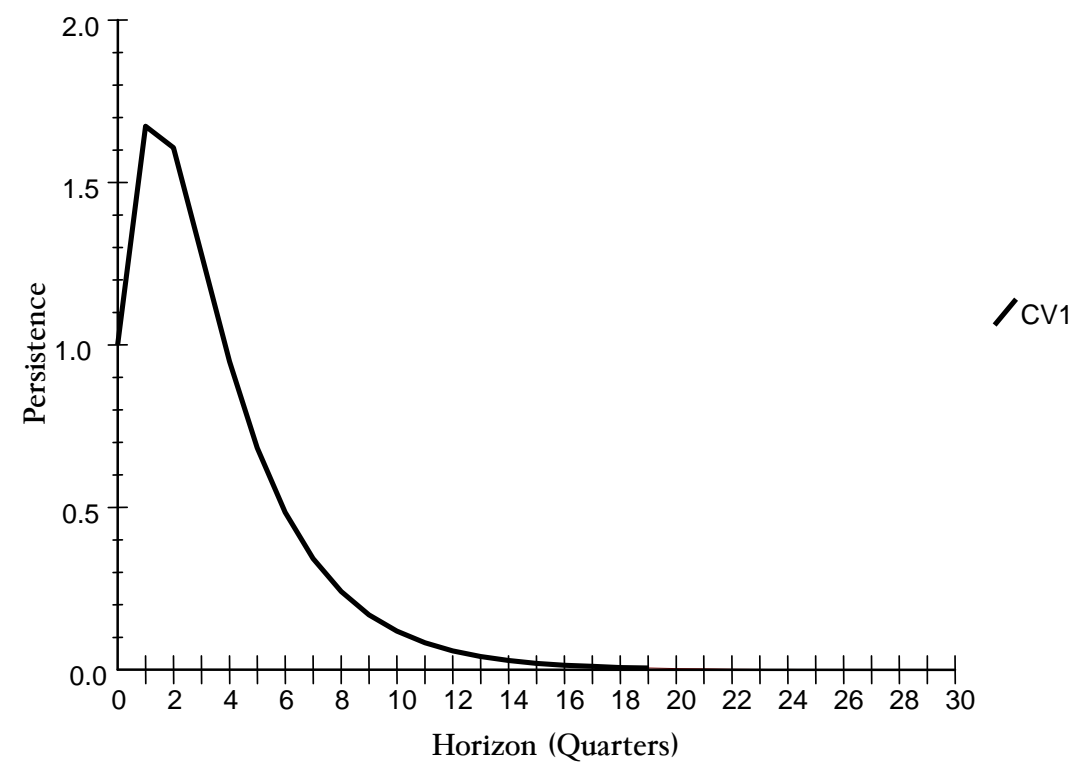

The persistence profile estimates show that the effects of systemwide shocks initially overshoot and eventually die out after 16 quarters (4 years). This implies that the adjustment towards the long-run equilibrium takes around 16 to 17 quarters ( 4 years). After 4 years, the marginal change in adjustment is not very significant. This implies that persistence profile of the PPP cointegrating vector converges rather slowly to its long-run equilibrium path after the introduction of a system-wide shock. The results further suggest that, on average, around $90 \%$ of disequilibrium is made up within almost 4 years. Such behavior is visible in Figure-3. The slow convergence of PPP comes from slow convergence of the exchange rate. Frankel (1990) argued that the failure of empirical studies to find evidence in favor of PPP is due to the low speed of adjustment towards PPP. Rogoff (1996) has also pointed out that observed persistence of the real exchange rate is far too high to be explained by existing models of PPP deviations. Engle and Morley (2001) argued that nominal exchange rates do converge at a much slower rate and about $60-90 \%$ of PPP disequilibrium adjustment takes place through nominal exchange rate adjustment. Rogoff (1996) discussed the PPP puzzle as:

The failure of short-run PPP can be attributed in part to stickiness in nominal prices; as financial and monetary shocks buffer the nominal exchange rate, the real exchange rate also changes in the short-run. This is the essence of Dornbusch's (1976) 
overshooting model of nominal and real exchange rate volatility. If this were the entire story, however, one would expect substantial convergence to PPP over 1-2 years, as wages and prices adjust to a shock (p. 654).

Figure-3 shows that initially, the profile starts increasing for some quarters after the shock and then it monotonically decreases up to the final adjustment. This inverted U-shape is also obtained by Pesaran and Shin (1996). A possible explanation for this overshooting and slow adjustment may be due to price stickiness, asymmetric information, less developed domestic markets, barriers to trade and productivity differentials. Another reason for this overshooting may be the J-effect characterizing the adjustment path of the current account in the presence of monetary shocks (Rogoff, 1996).

Based on the above outcomes, the transmission mechanism from monetary policy can be expressed as:

Increase in domestic money supply $(m)$ leads to an increase in domestic prices (i.e. pass-through effect), which subsequently increases the exchange rate $s$ (a depreciation). This implies that, despite real factors such as the budget deficit, monetary changes can affect both nominal exchange rates and domestic prices.

\section{Conclusions and Policy Implications}

This paper has examined the validity of unrestricted versions of PPP for Pakistan using quarterly data over the period 1982Q2 to 2005Q4 under the framework of multivariate cointegration and vector error-correction modeling approaches. We find one significant cointegrating vector, which indicates the presence of long-run relationship between the exchange rate, domestic and foreign prices. The important findings of the study include: first, the nominal exchange rate is cointegrated with domestic and foreign prices. The cointegration coefficient on the domestic price level is close to unity and the coefficient on the foreign price level is well below unity. However, the symmetry and proportionality conditions are not satisfied. These results support the validity of weak-form PPP in Pakistan. The errorcorrection terms are negative and significant implying that $12 \%$ and $0.04 \%$ of the past deviations from PPP are corrected by exchange rate and foreign price adjustments respectively per quarter. Second, the persistence profiles suggest that the adjustment of PPP towards the long-run equilibrium path is rather slow. Shocks to PPP are slowly absorbed and take 4-5 years to reach the final adjustment. Third, economic reforms helped to increase the 
flexibility of prices and nominal exchange rates in adjusting to short-term deviations and shortening the time span required for dampening these deviations ${ }^{16}$. The main policy implications drawn from this study include:

- The findings confirm that exchange rate, domestic and foreign prices are cointegrated. Therefore, the authorities can use PPP as a long-term nominal anchor to adjust to inflation differentials.

- To stabilize exchange rate and reduce deficits, monetary restraint is necessary.

\footnotetext{
${ }^{16}$ Empirical findings for developed countries suggest that the time period required for reestablishing PPP is shorter under floating exchange rate regimes; in this case, deviations from PPP could have a half-life as short as three to four years.
} 


\section{References}

Abuaf, N. and P. Jorion (1990), "Purchasing Power Parity in the Long Run," Journal of Finance, 45: 145-174.

Ahmed, Eatzaz and F. N. Khan (2002), "Short Run Dynamics in Purchasing Power Parity: A Case of Selected Asian Countries," The Middle East Business and Economic Review, 14(2).

Ardeni, P., and Lubian, D. (1991), "Is There Tend Reversion in Purchasing Power Parity," European Economic Review, 35: 1035-1055.

Ardeni, P., and Lubian, D. (1989), "Purchasing Power Parity During the 1920s," Economics Letters, 30: 357-362.

Baharumshah, A. Z. and M. Ariff (1997), "Purchasing Power Parity in South East Asian Countries Economies: A Cointegration Approach," Asian Economic Journal, 11(2): 141-153.

Bhatti, R.H. (1996), "A Correct Test of Purchasing Power Parity: The Case of Pak Rupee Exchange Rates," The Pakistan Development Review, 35(4): 671-682.

Bhatti, R.H. (2000), "On Purchasing Power Parity between Pakistan and Other Asian Countries," Pakistan Economic and Social Review, 38(1): $1-15$.

Boyd, D. and R. Smith (1999), "Testing for Purchasing Power Parity: Econometric Issues and an Application to Developing Countries," The Manchester School, 67(3): 287-303.

Casse1, G. (1918), "Abnormal Deviations of International Exchanges," Economic Journal, 28: 413-415.

Chinn, M.D. (1999), "Measuring Misalignment: PPP and East Asian Currencies in the1990s,” IMF Working Paper No. WP/99/120.

Chinn, M.D. (2000), "Three Measures of East Asian Currency Overvaluation," Contemporary Economic Policy, 18(2): 205-214.

Cheung, Y.W. and K.S. Lai (1993), "Long-Run Purchasing Power Parity During the Recent Float," Journal of International Economics, 34: 181-192. 
Cheung, Y.W. and K.S. Lai (1998), "Parity Revision in Real Exchange Rates During the Post-Bretton Woods Period", Journal of International Money and Finance, 17: 597-614.

Cheung, Y.W. and K.S. Lai (2000), "On Cross Country Differences in the Persistence of Real Exchange Rates," Journal of International Economics, 50: 375-397.

Cheung, Y.W., K.S. Lai and M. Bergman (2004), "Dissecting the PPP Puzzle: The Unconventional Roles of Nominal Exchange Rate and Price Adjustments," Journal of International Economics, 64: 135150.

Chishti, S., and M.A. Hasan (1993), "What Determines the Behaviour of Real Exchange Rate in Pakistan?" The Pakistan Development Review, 32(4): 1015-1028.

Civcir, I (2003), "Before the Fall, Was the Turkish Lira Overvalued?" Eastern European Economics, 41(2): 69-99.

Clarida, R and J. Gali (1994), "Sources of Real Exchange Rate Fluctuations: How Important are Nominal Shocks?” Carnegie-Rochester Series on Public Policy, 41: 1-56.

Coakley, J and A-M. Fuertes (2000), "Short-Run Real Exchange Rate Dynamics,” The Manchester School, 68(4): 461-475.

Corbae, C., and Ouliaris, S. (1988), "Cointegration and Test of Purchasing Power Parity," Review of Economics and Statistics, 70: 508-521.

Cooper, J.C. B. (1994), "Purchasing Power Parity: A Cointegration Analysis of Australian, Newzeland and Singaporean Currencies," Applied Economic Letters, 1: 167-171.

Crowder, W.J. (1992), "Purchasing Power Parity over the Modern Float: An Application in Higher Order Cointegration", Economics Letters, 40: 313-318

Goganlar, M. (1999), "Testing Long-run Validity of Purchasing Power Parity for Asian Countries,” Applied Economics Letters, 6: 147-151.

Dornbusch, R. (1988), "Exchange Rate and Inflation," Cambridge: MIT Press. 
Engle, C. (1992), "Real Exchange Rates and Relative Prices: An Empirical Investigation,” NBER Working Paper No. 4231.

Engle, C. (2000), "Long-Run PPP May Not Hold After Al1," Journal of International Economics, 51: 243-273.

Engle, C. and J. C. Morley (2001), "The Adjustment of the Prices and the Adjustment of the Exchange Rate," NBER Working Paper No. 4231.

Franke1, J. A (1990), "Zen and the Art of Modern Macroeconomics: The Search for Perfect Nothingness," in W. Haraf and T. Willett (eds), Monetary Policy for a Volatile Global Economy, The American Enterprise Institute for Public Policy Research Washington D.C.

Franke1, J. A and A. K. Rose (1996), "A Panel Project on Purchasing Power Parity: Mean Reversion Within and Between Countries," Journal of International Economics, 40: 209-224.

Frenke1, J. A. (1978), "Purchasing Power Parity: Doctrinal Perspectives and Evidence from 1920s," Journal of International Economics, 8: 169191.

Frenke1, J. A. (1981), "The Collapse of Purchasing Power Parity During 1970s," European Economic Review, 16: 145-165.

Froot, K. A. and K. Rogoff (1995) "Perspectives on PPP and Long-Run Real Exchange Rates," in G.M. Grossman, K. Rogoff (eds) Handbook of International Economics, (3): 1647-1688, North Holland, New York.

Giovannetti, G. (1989), "Testing Purchasing Power Parity as a Long-Run Equilibrium Condition,” Giornale Degli Economisti, 46: 491-508.

Gonzalo, J. (1994), "Five Alternative Methods of Estimating Long-Run Equilibrium Relationships,” Journal of Econometrics, 60: 203-233.

Habermeier, K. F. and M. Mesquita (1999), "Long-Run Exchange Rate Dynamics: A Panel Data Study," IMF Working Paper No. WP/99/50, International Monetary Fund.

Helg, R. and M. Serati (2000), "The Speed of Adjustment to PPP: Is There Any Puzzle?" Liuc Paper No. 74, Serie Economia e Impresa, 23.

Hendry, D. F. (1986), "Econometric Modelling With Cointegrated Variable: An Overview," Oxford Bulletin of Economics and Statistics, 48: 301-312. 
Huizinga, J. (1987), "An Empirical Investigation of the Long-Run Behaviour of Real Exchange Rates," Carnegie-Rochester Conference Series on Public Policy, 27: 149-214.

Janjua, M. A. (2004), History of the State Bank of Pakistan (1988-2003), Published by the State Bank of Pakistan, Karachi.

Johansen, S. (1988), "Statistical Analysis of Cointegrating Vectors," Journal of Economic Dynamic and Control, 12: 231-254.

Kamionsky, G. (1987), "The Real Exchange Rate in the Short and in the Long-Run,” Discussion Paper No. 3831, Department of Economics, University of California, San Diego.

Krugman, P. R. (1978), "Purchasing Power Parity and Exchange Rates: Another Look at the Evidence," Journal of International Economics, 8: 397-407.

Krugman, P. R. and K. Juselius (1990), "Maximum Likelihood Estimation and Inference on Cointegration with Application to the Demand for Money," Oxford Bulletin of Economic and Statistics, 52(2): 169210.

Lee, K. C. and M.H. Pesaran (1993), "Persistence Profiles and Business Cycle Fluctuations in a Disaggregated Mode1 of the U.K. Output Growth," Discussion Paper, University of Cambridge, Department of Applied Economics.

Liew, Venus, Khin-Sen, Ahmed Zubaidi Baharumshah and Terence TaiLeung Chong (2004), "Are Asian Real Exchange Rates Stationary?", Economics Letters, 38: 313-316.

Liu, P. C. (1992), "Purchasing Power Parity in Latin America: A Cointegration Analysis," Weltwirtschaftliches Archiv, 128: 662-679.

Lothian, J. R. (1990), "A Century Plus of Yen Exchange Rate Behaviour," Japan and the World Economy, 2: 47-70.

MacDonald, R (1993), "Long-Run Purchasing Power Parity: Is It for Real?" The Review of Economic and Statistics, 75: 690-695.

MacDonald, R and I.W. Marsh (1997), "On Fundamentals and Exchange Rates: A Casselian Perspective," The Review of Economic and Statistics, 79(4): 655-664. 
Mahadavi, S. and S. Zhou (1994), "Purchasing Power Parity in High Inflation Countries: Further Evidence,” Journal of Macroeconomics, 16: 403422.

McNown, R. and M. S. Wallace (1989), "National Price Levels, Purchasing Power Parity and Cointegration: A Test for Four High Inflation Countries," Journal of International Money and Finance, 8: 533545 .

Moosa, I. A. (1994), "Testing Proportionality, Symmetry and Exclusiveness in Long-Run PPP," Journal of Economic Studies, Vo1. 21, pp. 3-21.

Moosa, I. A. and R.H. Bhatti (1996), "Does Purchasing Power Parity Hold Between Japan and Other Asian Countries," Journal of International Economic Studies, 10: 85-94.

Nachane, D. M, and A. Chrissanthaki (1991), "Purchasing Power Parity in the Short and the Long-Run: A Reappraisal of the Post-1973 Evidence," Applied Economics, 23: 1257-1268.

Oh, K. Y. (1996), "Purchasing Power Parity and Unit Root Tests Using Pane1 Data," Journal of International Money and Finance, 15: 405-418.

Pape11, D. H. (1997), "Searching for Stationarity: Purchasing Power Parity Under the Current Float," Journal of International Economics, 43: 313-332.

Parikh, A., and G. Williams (1998), "Modelling Real Exchange Rate Behaviour: A Cross-Country Study," Applied Financial Economics, 8: 577-587.

Patel, J. (1990), "Purchasing Power Parity as a Long-Run Relation,” Journal of Applied Econometrics, 5: 367-379.

Peraran, M. Hashem, Yongcheol Shin and Rechard J. Smith (2000), "Structural Analysis of Vector Error Correction Models with Exogenous I (1) Variables,” Journal of Econometrics, 97: 293-343.

Peraran, M. Hashem, Yongcheol Shin and Rechard J. Smith (2001), "Bounds Testing Approaches to the Analysis of Level Relationships," Journal of Applied Econometrics, 16: 289-326. 
Qayyum, A., M. Arshad Khan and K. Zaman (2004), "Exchange Rate Misalignment in Pakistan: Evidence Based on Purchasing Power Parity Theory," The Pakistan Development Review, 43: 4.

Rogoff, K. (1996), “The Purchasing Power Parity Puzzle," Journal of Economic Literature, 34: 647-668.

Sarantis, N., and C. Stewart (1993), "Seasonality, Cointegration and the Long-Run Purchasing Power Parity: Evidence for Sterling Exchange Rates," Applied Economics, 25: 243-250.

Sercu, P., Uppal, R. and C. Van Hulle (1995), "The Exchange Rate in the Presence of Transaction Costs: Implications for Tests of Purchasing Power Parity," The Journal of Finance, 50: 1309-1319.

Shiller, R. J. and P. Perron (1985), "Testing the Random Walk Hypothesis: Power Versus Frequency of Observation," Economics Letters, 18: 381-386.

State Bank of Pakistan (2002), "Pakistan: Financial Sector Assessment 1999 2000," State Bank of Pakistan, Karachi, Pakistan.

Tang, M. and Ronald Q. Butiong (1994), "Purchasing Power Parity in Asian Developing Countries: A Cointegration Test," Report No.17 Asian Development Bak, Manila (Philippines), (1979).

Taylor, M. P. (1988), "An Empirical Examination of Long-Run Purchasing Power Parity Using Cointegration Techniques," Applied Economics, 20: 1369-1381.

Taylor, M. P. (1992), "Dollar-Sterling Exchange Rate in the 1920s: Purchasing Power Parity and the Norman Conquest of \$4.86," Applied Economics, 24: 803-811.

Taylor, M. P. and L. Sarno (1998), "The Behavior of Real Exchange Rate During Post-Bretton Woods Period," Journal of International Economics, 46: 281-312.

Wang, P. (2000), "Testing PPP for Asian Economies During the Recent Floating Period," Applied Economics Letters, 7: 545-548.

Whitt, J. A. (1992), "The Long-run Behavior of the Real Exchange Rate: A Reconsideration," Journal of Money, Credit and Banking, 24: 72-82. 
Wu, Y. (1996), "Are Real Exchange Rate Stationary? Evidence from a Pane1 Data Test," Journal of Money Credit and Banking, 28: 54-63.

Wu, J. L. and S. Wu (2001), "Is Purchasing Power Parity Overvalued?" Journal of Money, Credit and Banking, 33: 804-812.

Yunus, M. (2000), "The Validity of Long-Run Purchasing Power Parity in the South Asian Countries,” The Bangladesh Development Studies, 36(1): 99-124. 